\title{
55. Dilsel çevrenin dil öğretiminde kullanımı: Okuduğunu anlama becerisini geliştirmeye yönelik izlence önerisi
}

\section{İsmigül CANTÜRK1}

APA: Cantürk, İ. (2021). Dilsel çevrenin dil öğretiminde kullanımı: Okuduğunu anlama becerisini geliştirmeye yönelik izlence önerisi. RumeliDE Dil ve Edebiyat Araştırmaları Dergisi, (24), 973-986. DOI: $10.29000 /$ rumelide.995458.

$\ddot{\mathbf{O z}}$

Dilsel çevre, kamuya açık alanlarda kullanılan yazılı ve sözlü dilsel araçların tamamını tanımlamak için kullanılır. Dilsel çevre çalışmaları, çoğunlukla iki dilli toplumlarda halka açık alanlarda dillerin nasıl kullanıldığı, söz varlığı ve yabancı dillerin kamusal alanlarda kullanım durumunu incelemek amacıyla yapılmıştır. Fakat dil öğretiminde dilsel çevre kullanımı yeni bir çalışma alanı olarak karşımıza çıkar. Dilsel çevrenin dil öğretiminde kullanımı, özellikle iki dilli ve çok kültürlü toplumlarda olumlu ve olumsuz etkileri nedeniyle tartışılmaktadır. Fakat alan yazında yabancı dil olarak Çince öğretiminde girdi olarak dilsel çevre araçlarının kullanımına yönelik herhangi bir çalışmaya rastlanmamıştır. Çince yazı sistemi piktogram ve ideogramlardan oluşan bir dil olması nedeniyle imler günlük hayatta kamusal alanlarda ve sokaklarda yoğun şekilde yazılı iletişim aracı olarak bulunmaktadır. Sokaklar, caddeler, iş yerleri, metro istasyonları çeşitli tabela, yönerge, reklam, uyarı gibi çok sayıda Çince yazıyla doludur. Ayrıca bunlara ek olarak hükümetin halkı bilinçlendirmek ve kültürel değerlerini korumak için hazırlamış olduğu çok sayıda bilgilendirici tabela bulunmaktadır. Dolayısıyla Çince yazısı, toplum hayatında alfabetik dillere oranla daha yoğun şekilde yer alır. Çince öğretim aracı olarak kullanılması için geniş veri mevcuttur. Bu çalışma da yabancı dil öğretiminde dilsel çevre araştırmaları incelenmiş, dilsel çevre araçları kullanılarak Çince okuduğunu anlama ders örneği ve izlencesi hazırlanması amaçlanmıştır. Bu çalışmada nitel araştırma yöntemlerinden belge inceleme (doküman inceleme) tekniği kullanılmıştır. Çalışma sonunda oluşturulan ders izlencesi daha sonra yapılacak çalışmalara kaynak olabilecek niteliktedir.

Anahtar kelimeler: yabancı dil olarak Çince öğretimi, dilsel çevre, okuduğunu anlama becerisi

\section{The use of linguistic landscape in language teaching: A curriculum recommendation to improve reading comprehension skills}

\begin{abstract}
The linguistic landscape is defined as all written and spoken linguistic materials used in public spaces. Research on the linguistic landscape has been mostly carried out in bilingual societies to examine how languages are used in public spaces and the use of foreign languages in public spaces. However, the use of linguistic environment in language teaching emerges as a new field of study. The use of the linguistic environment in language teaching and its positive and negative effects, especially in bilingual and multicultural societies, are discussed. However, no study has been found in the literature on the use of linguistic landscape materials as input in teaching Chinese as a foreign language. Because Chinese writing system consist of logograms and pictograms Chinese characters are frequently found as a means of written communication in daily life, in public spaces and on the
\end{abstract}

Dr. Ars. Gör., Düzce Üniversitesi, Hakime Erciyas Yabancı Diller Yüksekokulu, Mütercim Tercümanlık Bölümü (Düzce, Türkiye), ismigulavci@duzce.edu.tr, ORCID ID: 0ooo-0001-8827-3449 [Araştırma makalesi, Makale kayit tarihi: 21.08.2021-kabul tarihi: 20.09.2021; DOI: 10.2900o/rumelide.995458]

Adres $\mid$ Address

RumeliDE Dil ve Edebiyat Araştırmalar Dergisi $\quad$ RumeliDE Journal of Language and Literature Studies Osmanağa Mahallesi, Mürver Çiçeği Sokak, No:14/8 $\quad$ Osmanağa Mahallesi, Mürver Çiçeği Sokak, No:14/8 Kadıköy - ISTANBUL / TURKIYE 34714 Kadıköy - ISTANBUL / TURKEY 34714 e-posta: editor@rumelide.com e-mail: editor@rumelide.com, tel: +90 505 7958124, +90 2167730616 phone: +90 505 7958124, +90 2167730616 
streets. Streets, avenues, workplaces and subways are full of various Chinese writings such as signs, instructions, advertisements, warnings. In addition to these, there are many signboards prepared by the government to raise public awareness and protect their cultural values. Therefore, Chinese characters takes place more intensely in social life than alphabetic languages. Extensive data are available for use as a teaching material. In this study, linguistic landscape studies in foreign language teaching were examined, and a Chinese reading comprehension lesson was prepared with the use of linguistic landscape materials. In this study, a course syllabus was prepared by using the document analysis technique, which is one of the qualitative research methods. In the study, linguistic landscape materals in public places were used as classroom material, and the importance of linguistic landscape materials in language acquisition as a authentic material was emphazised for future studies.

Keywords: linguistic landscape, teaching Chinese as a foreign language, reading comprehension skills

\section{Giriş}

Dilsel çevre (linguistic landscape) halka açık, sosyal alanlarda bulunan çeşitli yazıll, görsel araçların, metinlerin tamamı olarak tanımlanır (Cenoz ve Gorter, 2008; Herwitt-Bradshaw, 2014). Ana dili konuşucularının kullandığı ve toplum hayatı içinde karşılaştığı her türlü levha, tabela, reklam, ilan, sokak isimleri, işyeri tabelaları, yol işaretleri, interaktif ekranlar, duvar yazıları, basılı veya elektronik metinler, görsel-işitsel yazılı araçlar ve grafikler dilsel çevre olarak kabul edilir(Gorter, 2006). Dilsel çevre araçlarının amacı belirli bir kesim veya topluma hitap etmek, onlarla iletişim kurmak ve mesaj, bilgiyi yerine ulaştırmaktır.

Dilsel çevre ticari reklamlar, devlet uyarıları, bildiriler, çizimler, broşürler ve toplumsal alanda karşılaşılan tüm yazılı araçları kapsarken araştırma alanları çeşitlilik gösterir. İki dilli öğrenciler ve dilsel çevrenin eğitsel olarak kullanılması; dilsel çevre araçlarının bölgesel, dilsel, toplumsal ve kültürel, politik açıdan incelenmesi; reklam panoları, sokak isimleri, yer isimleri, iş yeri levhaları, kamu binaları üzerindeki yazılar, uyarıların kentsel, bölgesel dil görünümü dilsel çevrenin araştırma alanına girer (Chesnut, Lee ve Schulte, 2013). Dilsel çevre özel ve genel izler, işaretler taşır. Kamu otoriteleri (hükümet yetkilileri, belediyeler veya kamu acenteleri) veya bireyler, kuruluşlar, firmalar, şirketler dilsel çevrenin oluşmasında resmî düzenlemeler çerçevesinde yer alır. Dilsel çevrenin işlevi sadece bilgi verme amacı ile sınırlı değildir; bulunduğu bölgenin ve çevrenin iletişim kanalı olarak güçlü bir etkiye de sahiptir. Canada, Landry ve Bourhis dilsel çevrenin işlevinin iki dilli topluluklarda etnik dilsel canlılığın sürdürülmesi olduğuna da vurgu yaparlar. Spolsky ve Cooper ise siyasi rejimlerin dilsel çevrede etkisinin oldukça büyük olduğunu ifade ederler (akt Gorter, 2006, s.8).

\section{Dil öğretiminde dilsel çevre}

Dil öğretiminde öğrencilerin, gerçek dil ile yazılı veya sözlü olarak farklı şekillerde karşılaşması ve onu kullanması gerekir (Nation, 2009). Teknolojinin gelişmesi ile dilsel çevre araçlarının kolay ulaşılabilir olması, dil öğretiminde öğrencilere anlamlı deneyimler sunulması bakımından eğitimcilere yaratıcı firsatlar sunmaktadır (Herwitt-Bradshaw, 2014, s. 159-160). Yabancı dil öğretimi araştırmacıları da, öğrencilerin dil edinimlerini geliştirmek için dilsel çevrenin sunduğu firsatları kullanmak istemektedirler (Sayer, 2010). Çok dilli ve çok kültürlü toplumlarda eğitsel araç olarak dilsel çevrenin kullanılması ve değerlendirilmesi bu fırsatı yabancı dil öğretimi alanına da yansıtmıştır. Cenoz ve Gorter (2008), Rowland (2012), Sayer (2010) ve Thornbury (2012) dilsel çevrenin eğitsel araç olarak

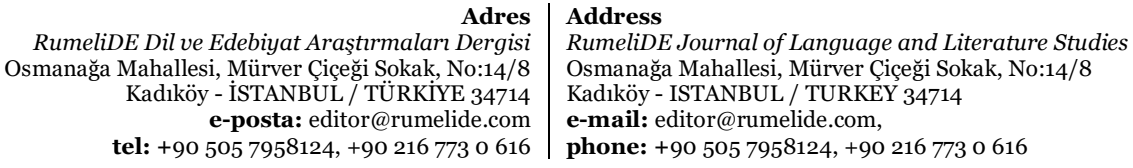


kullanımını araştırmış fakat sadece Rowland uygulamalı olarak çalışmıştır. Bu yüzden daha fazla eğitsel olarak uygulamalı çalışmalara ihtiyaç vardır (Chesnut vd., 2013).

Sayer (2010) dilsel çevreyi eğitsel araç olarak kullanmasının nedenini “İngilizce öğretmeni olarak, sınıfta işlediğimiz ders içeriğini öğrencilerin sınıf dışına taşımasını istiyordum, bu konuda zorlanıyordum. İkinci dil ediniminde dile maruz kalmanın ve kullanmanın önemli olduğunu biliyoruz; fakat öğrencilerin dile maruz kalma ve kullanma fırsatları sadece sınıf duvarları ile sınırlıydı.” sözleriyle açılar (s. 143).

Sayer (2010), Meksika Oaxaca'da topladığı İngilizce 250 adet ilan panosu, poster, işaret ve uyarı fotoğrafını tematik olarak sınıflandırmış ve sadece yüzde 12'sinin turistlere özel yazıldığını tespit etmiştir. Bir sınıf projesi olarak öğrencileri ile birlikte topladıkları malzemeleri analiz edip tematik olarak sınıflandıran Sayer (2010), bu uygulaması ile öğrenmeyi ders dışına taşımış ve öğrencilerin düzenleme, eleştirel düşünme, keşfetme becerilerinin gelişmesini ve farklı amaçlarla hazırlanmış sosyal dil kullanımını görmelerini sağlamıştır. Ayrıca bu çalışma, dilsel çevrenin öğrenen özerkliğini geliştirdiğini de göstermiştir. Dilsel çevre etkinlikleri, öğrencilerin kendi araştırma alanlarını keşfetmesi, öğrenme araçları ile bağımsız etkileşim kurması ve düzenlemesi açısından etkili bir yoldur (Barrs, 2016). Benzer bir çalışmada ise Rowland (2012), öğrencilerinin topladığı İngilizce ilan, işaret, reklamlar gibi dilsel çevre araçları ile Japonya'daki dilsel çevrede İngilizcenin nasıl bir görünümde olduğunu araştırmış; dilsel çevre araçlarının, öğrencilerin çoklu okuryazarlık ve soyut düşünme becerilerini geliştirdiği sonucuna ulaşmıştır.

Okuduğunu anlama becerisi, geleneksel olarak yazılı dilin işlenmesi iken dilsel çevre çoklu (multimodal) okuryazarlık gerektirir. Metnin fiziksel özelliği, nerede bulunduğu, hangi durumlarda ve hangi amaçlarla kullanıldığına bağlı olarak okumaya yeni anlamlar yüklenir. Bu bakımdan dilsel çevre hem görsel hem basılı araç olarak, çeşitli amaç ve özellikler barındırır; öğrencilerin farklı okuma-anlama deneyimi kazanmalarını sağlar (Gorter,2006 ).

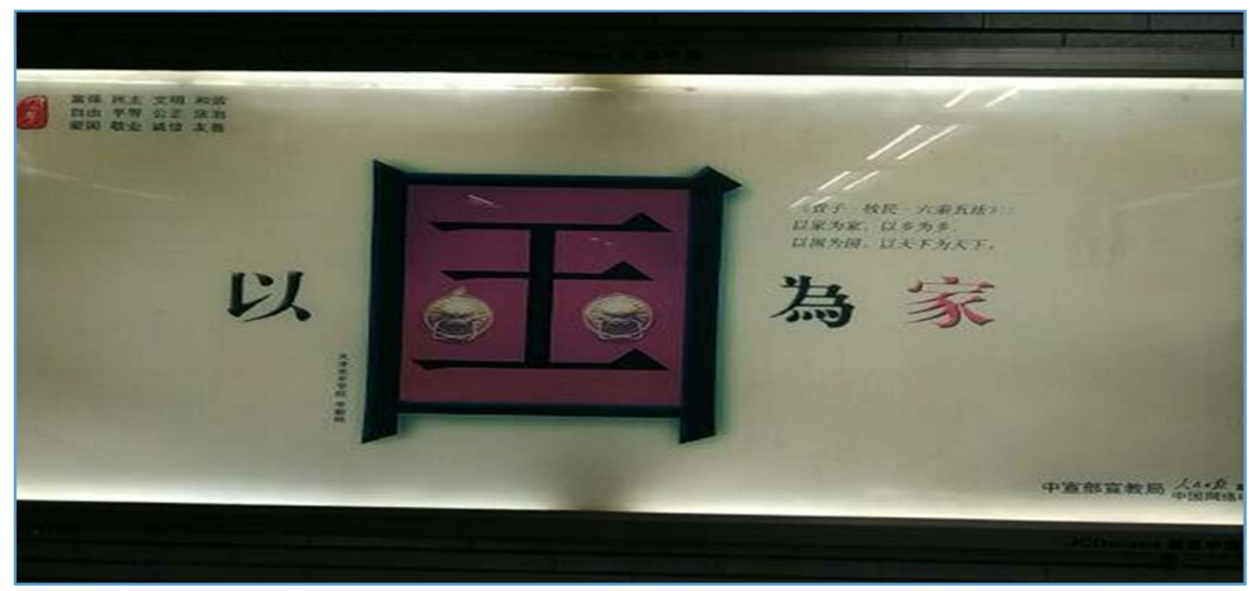

Fotoğraf 1. Nanjing metro durağı billboardı

Fotoğraf 1. Nanjing metro istasyonunda, hükümet aracıllğıyla yerel yönetim tarafindan bilboardlara yerleştirilmiş fotoğraflardan biridir. M.Ö 770-476 yllları arasında yaşamış ünlü düşünür Guanzi’nın (管 子) “以国为家 - Ülkeni ailen gibi gör. 以家为家, 以乡为乡, 以国为国, 以天下为天下.” sözlerinden alınt yapılmış. Büyük kitleye ulaşılması ve toplum düzeninde kültürel değerlerin korunması ve hatırlanması hedeflenmiştir. Temel düzey Çince bilgisi ile bu ifadeyi anlamak mümkündür.

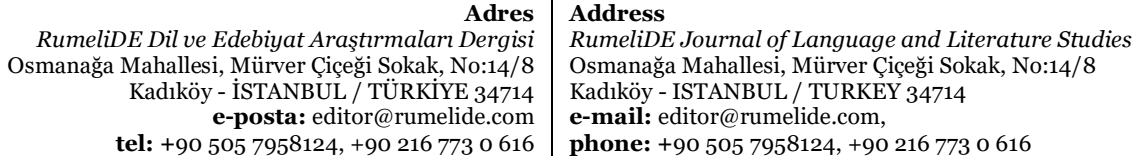


Multimedya teknolojileri, iletişim kanalları ve medyanın hızla gelişimi beraberinde çoklu okuryazarlık becerilerinin ortaya çıkmasını sağlamıştır. Sesler, semboller ve çok sayıda yazı içeren simgenin okunmasını gerekli kılmıştır. Bu değişim, eğitimde ve dil öğretiminde yenilikleri beraberinde getirmiştir. Dilsel çevre, çeşitli kaynaklardan gelen bilgileri eleştirel okumayı, yorumlamayı ve değerlendirmeyi öğretir. Bu beceri, 21. yüzyılda internet ve sosyal medya araçlarında paylaşılan mesaj, alt mesaj, reklam ve bilgilerin doğru okunup anlaşılması için gerekli yeni bir beceri olarak oldukça önemlidir.

\section{Araştırmanın amacı}

$\mathrm{Bu}$ çalışmanın amacı, kalıcı ve etkin öğrenme sağlamak amacıyla dilsel çevre araçları ile Çince okumaanlama ders izlencesi hazırlamaktır. Çalışmanın gerçek dil kullanımına örnek oluşturması nedeniyle alana katkı sağlayacağı ve yenilik getireceği düşünülmektedir. İngilizce öğretimi alan yazında dilsel çevre araçları ile çeşitli çalışmalar yapılmış ve olumlu sonuçlar kaydedilmiştir. Fakat yabancı dil olarak Çince alan yazında herhangi bir çalışmaya rastlanmamıştır. Bu çalışma ile yabancı dil olarak Çincenin öğretiminde de dilsel çevre araçları ile okuma öğretiminin yapılabileceği örneklendirilmiştir. Öğrenciler dilsel çevre araçlarından faydalanarak gerçek dil kullanımını anlayabilirler, bu durum öğrenmeyi daha kalıcı ve günlük hayatta kullanılabilir kılabilir. Bu gerekçelerden yola çıkarak yabancı dil olarak Çince okuma öğretiminde dilsel çevre kullanımının uygulanabilirliğini örnek bir ünite izlencesi ile ortaya koymanın önemli olduğu düşünülmektedir.

\section{Yöntem}

Bu çalışmada dilsel çevre araçlarının kullanımı ile oluşturulması amaçlanan okuma-anlama ders örneği için gerçek dil ortamında üzerinde yazı bulunan çok sayıda fotoğraf nitel araştırma yöntemi ile incelenmiştir. Araştırmacı tarafından çekilen fotoğraflar dil seviyeleri, amaçları ve bulundukları ortama göre sınıflandırılmıştır. Belge incelemesi (doküman analizi) tekniği ile çalışmanın amacı doğrultusunda çok sayıda fotoğraf taranmış ve tema oluşturulmuştur. Seçilen temaya uygun olan fotoğraflar, ünite metni ve etkinliklerde kullanılmıştır. Belge incelemesi nitel araştırma tekniği olarak dil bilimi ve dil öğretimi alanında sıkça kullanılmaktadır. Belge inceleme yazılı ve elektronik araçları ayrıntılı ve sistematik olarak analiz etmek için kullanılan bir nitel araştırma yöntemidir. Nitel araştırmanın temel özelliği olarak belge inceleme ilgili konuda bilgi toplama, verilerin incelenmesi ve değerlendirilmesini gerektirir (Corbin \& Strauss, 2008). Belge, araştırmacının müdahalesi olmadan kaydedilmiş metinleri ve fotoğrafları içerir.

$\mathrm{Bu}$ çalışmada betimsel araştırma yöntemlerinden yararlanılmıştır. Alanyazın taraması yapılmış ve özgün dilsel çevre araçları araştırmacı tarafından toplanmıştır. Kullanılan fotoğraflar araştırmacı tarafından 2017 yllında Çin/Nanjing ve 2019 yllında Çin/Hangzhou şehrinde çekilmiştir.

\section{Araştırmanın planlanması}

Araştırma verileri ve alanyazın önerilerine göre hazırlanan ünite örneği, özgün ve dilsel çevre araçları kullanılarak geliştirilmiştir. Okuma alt becerileri, hazırlanan ünitenin temel öğrenme hedefleri olarak belirlenmiş ve bu doğrultuda temalar, etkinlikler şekillenmiş ve ünite oluşturulmuşstur. Orton ve Cui'a göre (2016) ders ünite hazırlama ilkeleri; konuyu seçme, içeriğin oluşturulması, öğrenme hedeflerinin belirlenmesi, dersin planlanması, etkinlik ve stratejilerin tasarlanması, öğretme ve sınama tekniklerinin seçilmesi olarak sıralanır.

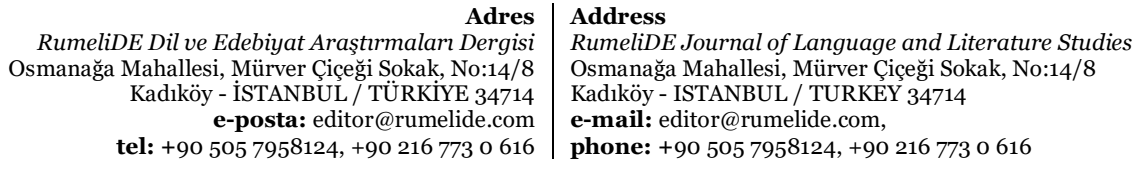


Okuma alt becerileri yabancı dil öğretimi alanyazınına göre belirlenmiş; üniteler, etkinlikler Çince dil yapısı çerçevesinde $\mathrm{HSK}^{2} 5$ düzey okuma yeterliklerini kapsayacak şekilde tasarlanmış ve CEFL - C1 okuduğunu anlama yeterlikleri ile desteklenmiştir. Okuma becerisinin anlama ve kavrama düzeyine orta-ileri düzeyden sonra ulaşılması nedeniyle düzey olarak HSK 5 belirlenmiştir. CEFL ve HSK birbirinden farklı okuma dil beceri tanımlayıcılarına sahip olsa da ortak noktaları da bulunmaktadır.

HSK 5 düzey yeterlikleri aşağıdaki gibidir: (s.27)

İleri seviye (HSK 5) öğrencileri belirli uzunluktaki, nispeten karmaşı, dilsel araçlarda ana-fikri bulabilir, ayrıntılı ve önemli bilgileri ve metin yapısını anlayabilir. Bunlar dört maddede toplanır:

1. Belirli uzunluktaki eleştiri türündeki metinlerin ana-fikrini bulabilir, metindeki ayrıntılı ve önemli bilgileri ve metin yapısını anlayabilir.

2. Belirli uzunluktaki atasözü, deyim mecaz içeren anlatı/hikâye metinlerini, vermek istediği mesajı doğru anlayabilir.

3. Yeni sözcüklerin ve terimlerin bulunduğu tanıtıcı veya betimleyici araçları anlayabilir, gerekli önemli bilgileri bulabilir.

4. Meslek, öğrenim ve yaşamla ilgili popüler bilim vb. metinlerini anlayabilir.

HSK müfredat içeriğinde, okuma öğretiminde kullanılabilecek metin türleri ve araçlar belirtilmemiştir. Çalışmada Avrupa Dil Gelişim Dosyasında önerilen metinler, Çince okuduğunu anlama araçlarında çok nadir yer verilen ve Çin'de günlük hayatta sık karşılaşılan özgün metinler kullanılmış ve metin tür çeşitliliği sağlanmıştır. Avrupa Dil Gelişim Dosyasında temel düzey (A1 ve A2) okuma becerileri için basit gazete haberleri, kişisel bilgiye ilişkin anketler, duyuru tabloları, günlük yaşamda karşılaşılan uyarılar, bilgisayarda karşılaşılan temel komutlar, yönlendirmeler, basit mesajlar, broşürler, reklamlar, basit yönergeler, kısa öyküler önerilir. Orta düzey (B1 ve B2) için yukarıda belirtilen türlere ek olarak röportaj, köşe yazıları, haber özetleri, resmî ve özel mektuplar, öyküler, raporlar, makaleler, eleştiri yazıları önerilir. İleri düzey ( $\mathrm{C}_{1}$ ve $\mathrm{C} 2$ ) için ise karmaşık raporlar, analizler, uzun ve karmaşı yönergeler, yazışmalar, sosyal, politik ve tarihsel içerikli yazınsal metinler, yönetmelikler, kontratlar, şiir, düzyazı, drama biçimindeki klasik eserler gibi metinlerin kullanılması gerektiği belirtilir. Öğrenciler notlar, işaretler, uyarılar, internet metinleri, gazete metinleri, edebi metinler gibi bütün metin türlerini okumalıdır (Xing, 2006, s. 26).

Metin zorluk düzeyi C1/HSK 5 olarak belirlenmiş olsa da metinde C1 üzeri (C2/HSK6) sözcükler de bulunmaktadır. Krashen'e göre (1985) girdi hipotezine göre öğrencilerin dil edinimleri, ancak mevcut dil düzeylerinden biraz daha zor yapılar içeren bir dili anladığında gerçekleşir. Edinimin gerçekleşmesi öncelikle anlaşılır (daha kolay anlaşılır) ve devamında zor anlaşılır girdinin sunulması ile mümkündür. $\mathrm{Bu}$ nedenle, ünitede mevcut düzey ve düzeyin bir üstü bilgilere de yer verilmiştir.

Okuduğunu anlama becerisini geliştirmeye yönelik yöntembilimsel ilkelere göre okuma etkinlikleri üçe ayrılır. İlk aşama ısınma etkinlikleri (warm-up activity) okuma öncesinde yer alır. Okuma sırasında ise öğrencilerin bazı dikkat çekici ayrıntıları takip etmeleri istenir. Okuma sonrasında ana-fikri anlama

2 Çince Yeterlilik sınavı HSK (Hanyu Shuiping Kaoshi), Çin Halk Cumhuriyeti'nin anadili Çince olmayanların Çince dilindeki yeterliliklerini ölçmek için uyguladı̆̆ı tek resmî sınavdır.

Adres Address

RumeliDE Dil ve Edebiyat Araşttrmaları Dergisi $\quad$ RumeliDE Journal of Language and Literature Studies Osmanağa Mahallesi, Mürver Çiçeği Sokak, No:14/8 $\quad$ Osmanağa Mahallesi, Mürver Çiçeği Sokak, No:14/8 Kadıköy - ISTANBUL / TURKIYE 34714 Kadıköy - ISTANBUL / TURKEY 34714 e-posta: editor@rumelide.com $\quad$ e-mail: editor@rumelide.com, tel: +90 $5057958124,+902167730616$ phone: +90 505 7958124, +90 2167730616 
etkinliklerine, amaca yönelik bilginin anlaşılmasını sağlayan etkinliklere yer verilir (Sarosdy vd., 2006, s. 55-56). Çalışmanın ders izlencesi bu yöntembilim çerçevesinde şekillendirilmiştir.

$\mathrm{Bu}$ çalışmada etkinlikler, seçilen metinlere göre okuma becerilerini geliştirecek strateji ve teknikleri kapsayacak şekilde okuma öncesi, okuması sırası ve okuma sonrası olmak üzere tasarlanmıştır. Etkinlik araçları metin içeriklerine uygun olacak şekilde fotoğraflar, reklamlar, panolar, uyarılar, ilanlar görsel malzeme ve dilsel çevre fotoğraflarından, özgün metinlerden oluşturulmuştur.

\section{Bulgular ve yorum}

Hazırlanan okuduğunu anlama ders izlencesine ait bilgiler aşağıdaki gibidir:

\begin{tabular}{|c|c|c|c|c|c|}
\hline $\begin{array}{l}\text { Ünite: İş } \\
\text { ilanları } \\
\text { Ders }\end{array}$ & $\begin{array}{l}\text { Hedeflenen } \\
\text { okuma } \\
\text { becerileri: }\end{array}$ & $\begin{array}{l}\text { Etkinlik/sınama: } \\
\text { Açık uçlu sorular }\end{array}$ & $\begin{array}{l}\text { Araçlar: } \\
\text { İlan, duyuru, } \\
\text { reklam fotoğrafları }\end{array}$ & $\begin{array}{l}\text { Metin } \\
\text { türleri: } \\
\text { Bilgilendirici. }\end{array}$ & $\begin{array}{l}\text { Dil } \\
\text { yapıları: } \\
\text { V+于 }\end{array}$ \\
\hline saati: 4 & Gözden geçirme & Tablo doldurma & (Dilsel çevre) & özö̈n & 从事 \\
\hline Düzey: & Tarama & $\begin{array}{l}\text { Doğru-yanlış/var- } \\
\text { yok }\end{array}$ & & $\begin{array}{l}\text { Ozgun, } \\
\text { olușturulmuș }\end{array}$ & \\
\hline SК 5 & Çıkarım yapma & & & (yapay) & \\
\hline & $\begin{array}{l}\text { Karşılaştırma } \\
\text { yapma }\end{array}$ & & & & \\
\hline & Sentezleme & & & & \\
\hline
\end{tabular}

Tablo 1. Ünite çerçevesi

Okuduğunu anlama dersi için gözden geçirme, tarama, çıkarım yapma, karşılaştırma ve sentezleme geliştirilmesi hedeflenen okuma alt-becerileri olarak belirlenmiştir. Bu ünitede, iş ilanı ve özgeçmiş dersin teması olarak seçilmiştir. İş ilanı ve özgeçmiş temasına uygun özgün araç olan fotoğraflar belirlenmiştir. Tema için fotoğraf seçimi yapılırken ve etkinlik oluşturulurken ana dili konuşucusu ve Türk uzman görüşüne başvurulmuştur. Ders süresi olarak 4 ders saati belirlenmiştir. Etkinliklerde açı uçlu sorular, tablo doldurma, doğru-yanlış, var-yok sınama teknikleri kullanılmıştır. Sadece sözcük öğretimine yönelik bir ders planlanmadığı için ayrıntılı sözcük öğretimi etkinliklerine yer verilmemiş, okuduğunu anlama alt becerilerinin geliştirilmesi hedeflenmiştir. Önemli dilsel yapılar ve bilinmeyen sözcüklerin öğretmen tarafından açılaması planlanmıştır. Ders izlencesi üç aşamadan oluşturulmuştur:

1. Aşama: Isınma amaçlı okuma öncesi etkinlikler

2. Aşama: Ünite metni ve ünite sonu etkinlikleri

3. Aşama: Dilsel bilgi ve ödev

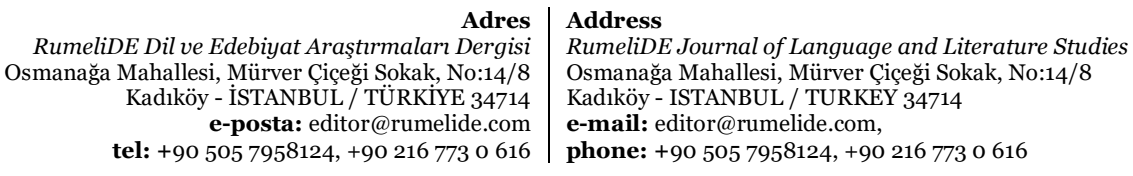


1. Aşama: Isınma (热身/warm up)
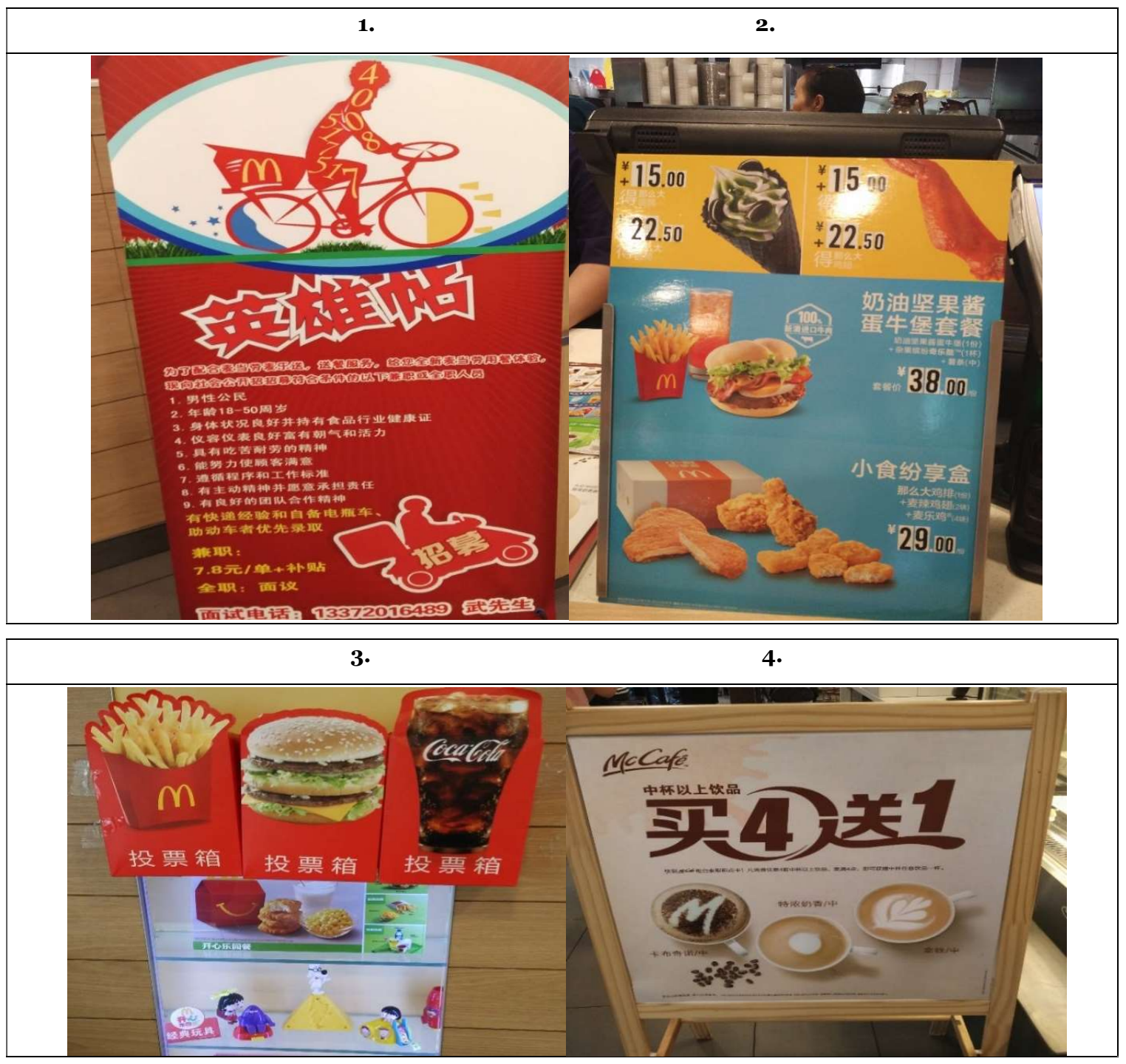

Fotoğraf 2. Isınma etkinliği

\section{1. 以上的麦当劳广告中找到不同的并解释一下它为什么不同？}

(Yukarıdaki McDonald's ait dört farklı reklam panosunu inceleyiniz, farklı olanı bulunuz. Neden farklı olduğunu açıklayınız.)

Birinci aşamada okuma öncesi ısınma etkinliği olarak öğrencilere dört farklı fotoğraf gösterilir. Fotoğrafların nerede, hangi amaçla bulunduğu sorulur. Fotoğraflar tek tek incelenir, üzerindeki yazılar hızlıca taranır, öğrencilerin fotoğraflardaki tüm imleri tanımaları ve anlamaları beklenmez. Göz gezdirme ile amacı farklı olan fotoğrafı tahmin etmeleri ve yorum yapmaları istenir. Öğrencinin iş ilanlarına dair önbilgilerinin ortaya çıkarılması amaçlanır. Bu fotoğrafların renkli olarak projeksiyon cihazı ile yansıtılması reklam panosunun gerçekliğini bire bir yansıtması açısından oldukça önemlidir. Reklamların dördü de restoran reklam panosunda asılıdır ve içlerinden sadece biri iş ilanıdır. Restoran

\footnotetext{
\begin{tabular}{r|l} 
Adres & Address \\
RumeliDE Dil ve Edebiyat Araştırmaları Dergisi & RumeliDE Journal of Language and Literature Studies
\end{tabular} Osmanağa Mahallesi, Mürver Çiçeği Sokak, No:14/8 $\quad$ Osmanağa Mahallesi, Mürver Çiçeği Sokak, No:14/8 Kadıköy - İSTANBUL / TÜRKIYE 34714 Kadıköy - ISTANBUL / TURKEY 34714 e-posta: editor@rumelide.com e-mail: editor@rumelide.com, tel: +90 505 7958124, +90 2167730616 phone: +90 505 7958124, +90 2167730616
} 
içinde iş ilanı, reklam gibi büyük panoya asılmıştır. Bu etkinlik ile öğrencilerin reklam panolarının amaçlarını anlamaları ve sorgulama yapmaları hedeflenir. Bu etkinlikte sınama tekniği olarak açlk uçlu soru-cevap kullanılmıştır. Öğrencinin kendi ifadelerini birkaç sözcükle yazmaları ve söylemeleri istenir. Öğrencinin zihinsel olarak konuya hazırlanması sağlanır.

\section{2. 以下的两个麦当劳广告上招募哪些职位，请填空。有的画 $(\sqrt{ })$ 没有的画 $(x)$}

(Aşağıdaki iki McDonald iş ilanında hangi pozisyona eleman aranıyor, aşağıdaki tabloda birinci ve ikinci ilanda aranan iş pozisyonlarını işaretleyiniz $(\sqrt{ })(\mathrm{x}))$

职位 iş pozisyonu
服务员 garson
咖啡师 barista
员工 hizmet elemanı
品牌大使 marka temsilcisi
接待员 resepsiyon görevlisi

$$
\text { 第一广告Birinci ilan 第二广告İkinci ilan }
$$

$\mathbf{X}$
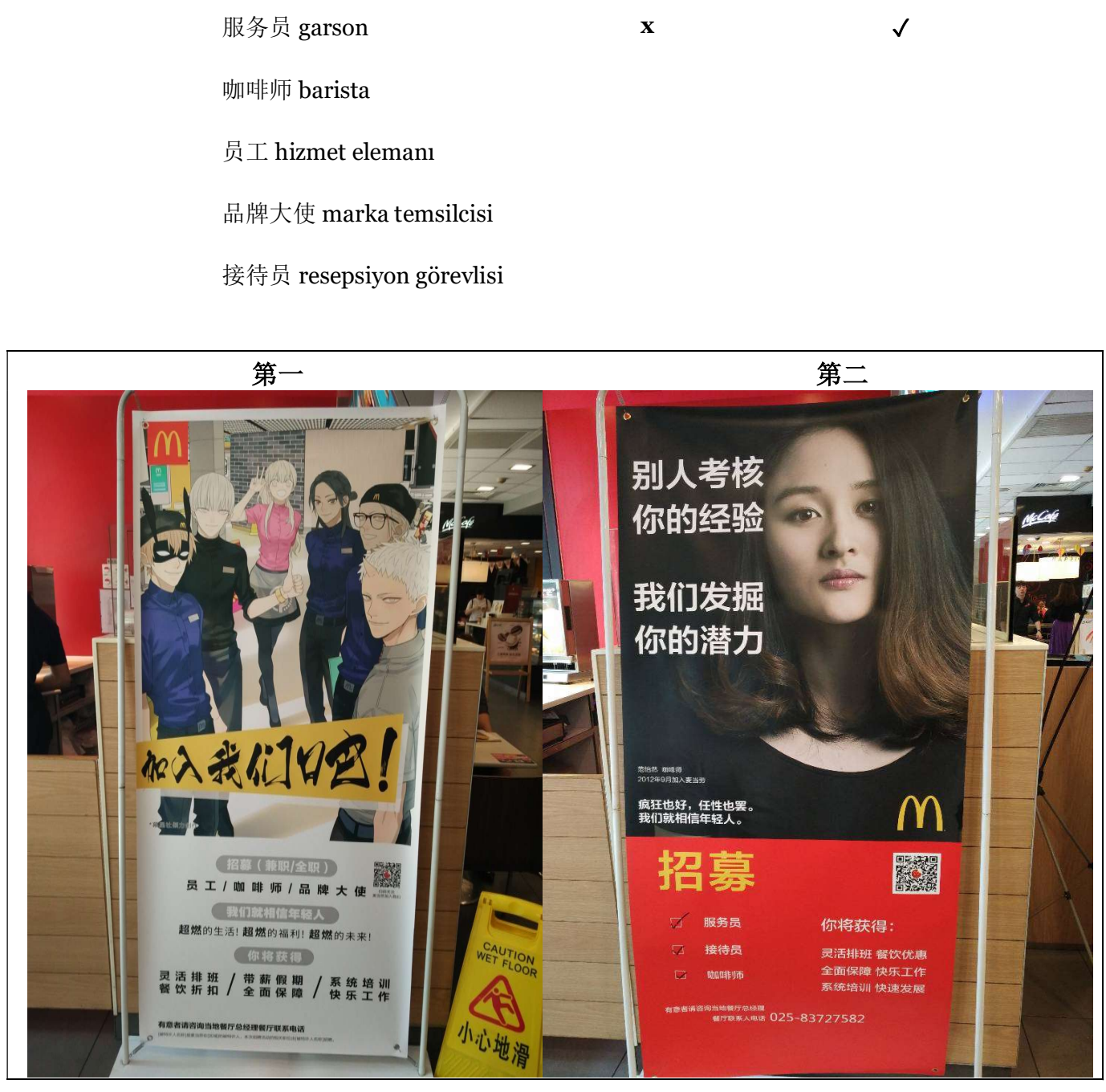

Fotoğraf 3. Isınma etkinliği 2.

Isınma etkinliğinin devamı olarak daha ayrıntılı açıklamaları olan iki iş ilanı fotoğrafı kullanılır, aynı yiyecek sektörünün farklı pozisyona göre hazırlamış olduğu iş ilanı öğrencilere gösterilir. Birinci ve ikinci ilanda aranan iş pozisyonlarını bulup tabloda doldurmaları istenir. Birinci ısınma etkinliğinde iş

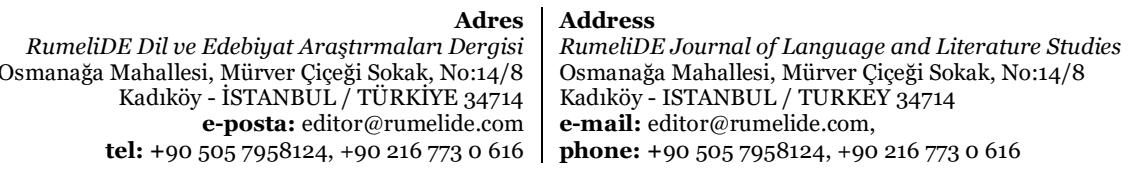


ilanının nasıl olduğu bu ilanda ise iş ilanında bulunan sözcüklerle karşılaşmaları ve daha dikkatli okumaları beklenir. İlanlardan birincisinde bir grup anime resmi kullanılmış ve ikincisinde ise genç bir kadın resmi açıklama kısmından daha büyük boyutta yer almıştır; iki ilanda da yiyecek sektörünün iş ilanı olduğu okumadan anlaşılmamaktadır. İkinci fotoğraf daha çok şampuan reklamı gibi dururken açılklamalar okununca ancak yiyecek sektörü iş ilanı olduğu anlaşılmaktadır. Bu etkinlikte tablo doldurma $(\sqrt{ }-\mathrm{x})$ sınama tekniği kullanılmıştır. İlanda aranan ve aranmayan iş pozisyonlarının bulunması istenmiştir.

2. Aşama: Ünite metni

\section{课文一、阅一读以下的职位发布并回答问题。}

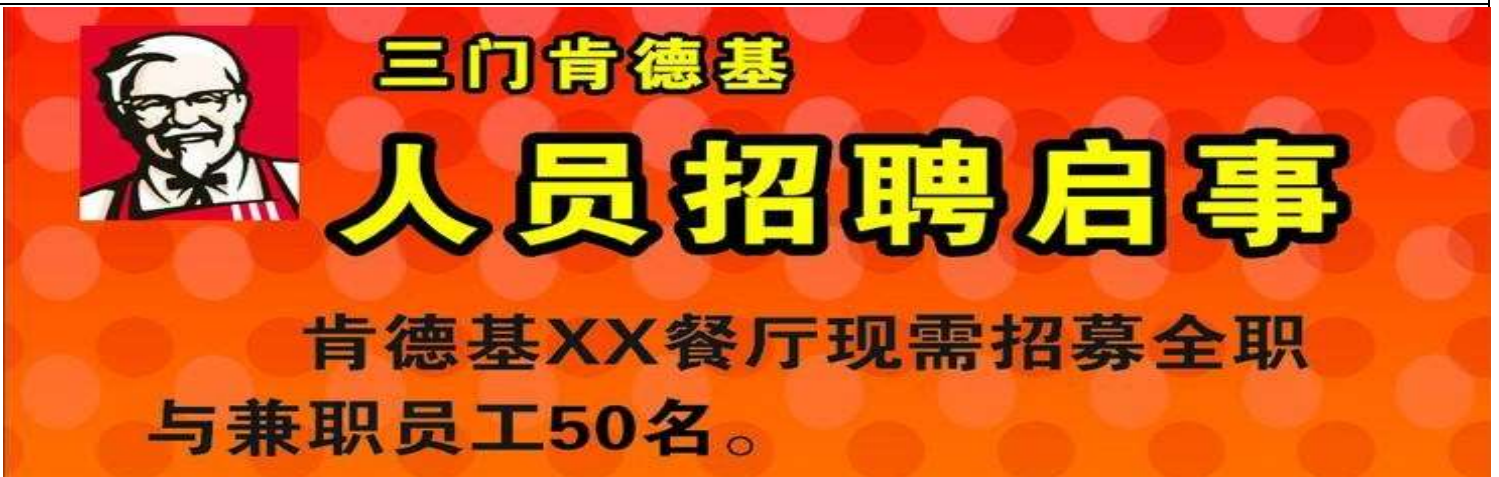

要求8 年龄在18-30周岁，提供初中及以上毕业证书。

上班时间8 全职每天8-9小时;

兼职每天4-8小时;

学生提供周末及寒暑假时间

工冾待遇8 1。按小时薪资。月结;

2。月工时超167小时亨受公司1.5倍小时薪资的 加班补贴;

3、全职工资月工资在 $1500-2000$ 之间。并享有 每月6-8天的休息时间。月上班时间不超过 200个小时。

圆正湢利8 1。公司缴纳养老保险。医疗保险及住房公积金 等国家保障福利8

2。国家法定节假日亭受3倍工资待遇8

3. 通曾班亨受额外早晚班津贴B

4。亨受公司相关带薪年假。

Fotoğraf 4. Ünite metni

Ünite metni olarak hızlı yemek restoran zincirlerinden birinin iş ilanı kullanılır. Ünite metni olarak seçilen ilandaki bilinmeyen sözcükler öğrencilere açıklanır. Özellikle iş ilanlarında kullanılan yapılar, tanımlamalar açıklanır ve metin etkinlikleri yapılır.

RumeliDE Dil ve Edebiyat Araştırmaları Dergisi Osmană̆a Mahallesi, Mürver Çiçeği Sokak, No:14/8 Kadıköy - ISTANBUL / TÜRKIYE 34714 e-posta: editor@rumelide.com tel: +90 $5057958124,+902167730616$
Address

RumeliDE Journal of Language and Literature Studies Osmanağa Mahallesi, Mürver Çiçeği Sokak, No:14/8 Kadıköy - ISTANBUL / TURKEY 34714

e-mail: editor@rumelide.com,

phone: +90 5057958124 , +90 2167730616 


\section{Okuma etkinliği}

\section{情况 Durum}

1. 大学一年级的学生海姻每天下课以后要上班。

2. 她老婆没有初中毕业证书但是他找工作。

3. 我今年大学毕业了但没收到毕业证书。

4. 因有小宝贝 28 岁的老婆要兼职工作。

5. 我现在的工资 2200 元, 但不够用于我的家庭支出。

\section{可申请 不可申请}

\section{Başvurabilir Başvuramaz}

Tablo 2: Okuma Etkinliği 1

Metin öğrencilerle birlikte okunup incelendikten sonra metin sonu etkinliği olarak tablo doldurma etkinliği hazırlanmıştır. Okuduğumuz iş ilanında aranan özelliklere uygun olan ve uygun olmayan beş farklı kişi özellikleri tablodaki beş cümlede kurgu şekilde oluşturulmuştur. Oluşturulan beş farklı kişi özelliklerine göre yukarıdaki iş ilanına başvurup başvuramayacaklarını bulmaları ve işaretlemeleri öğrencilerden istenir. İş ilanına neden başvurabildikleri/başvuramadıkları ve hangi şartlara uygun olup/olmadıkları iş metnin üzerinde ayrıntılı işlenir.

Örneğin birinci soruda üniversite birinci sınıfa giden Haimei, dersi olmadığı zamanlarda çalışmak istiyor. Bu durumda yukarıdaki ilana başvurabilir mi başvuramaz mı? Haimei için bu iş ilanı uygun mudur, nereden anlıyoruz? İş ilanında yarım gün çalışma kabul ediliyor mu, çalışma saatleri esnek olabiliyor mu, çalışma saatleri dikkatli okunarak bu sorunun doğru cevabı bulunur.

Cümlelerin her biri birbirinden bağımsız kurgu şekilde oluşturulmuştur. Öğrencinin bu beş soruyu cevaplamak için öncelikle cümledeki durumu anlaması, ilandan o duruma uygun olup olmadığını bulması ve ilanı baştan sona taraması ve ayrıntılı anlaması gerekir. Öğrencinin okuma metnini anladıktan sonra verilen cümlelerdeki kişilerin özelliklerini anlaması, çıkarım yapması, bilgiyi sentezlemesi ve bağlantı kurması gerekir.

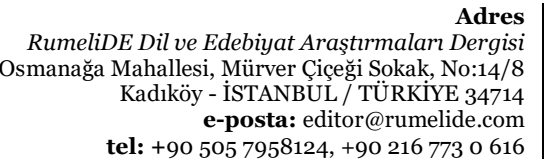

Address

RumeliDE Journal of Language and Literature Studies Osmanağa Mahallesi, Mürver Çiçeği Sokak, No:14/8

Kadıköy - ISTANBUL / TURKEY 34714

e-mail: editor@rumelide.com,

phone: +90 $5057958124,+902167730616$ 


\section{Okuma etkinliği}

岗位要求:

1、中国人，女性，形象好，气质佳，年龄在20-30岁;

2、1年以上相关工作经验，文秘、行政管理等相关专业优先考虑;

3、熟悉办公室行政管理知识及工作流程，具备基本商务信函写作能力及较 强的书面和口头表达能力;

4、熟悉公文写作格式, 熟练运用OFFICE等办公软件;

5、工作仔细认真。

6、语言; 中文, 不需土语

7、工作地点：伊斯坦布尔

联系方式

电话: 75312214690

邮箱: infoh@jjhnnn.com

Tablo3. İşilanı 1招募一

\begin{tabular}{|c|c|c|c|c|}
\hline 部门 & 㐫位名称 & 㐫位职表 & 㐫位要求 & 人数 \\
\hline 巴南支行 & 综合管理玄 & $\begin{array}{c}\text { 负责支行的综合文 } \\
\text { 婆、行政后勤、财 } \\
\text { 务管理、安全保蛋 } \\
\text { 人员管理等相关 } \\
\text { 工作。 }\end{array}$ & $\begin{array}{l}\text { 年龄30周岁以下, 全日制本科及以上 } \\
\text { 学历; 具备较强的语言表达能力、沟 } \\
\text { 通协调能力和组织管理能力, 擅长公 } \\
\text { 文写作, 具有两年以上银行丛经验 } \\
\text { 或者大型机,关事业单位工作经验优 } \\
\text { 先; 身心健康, 品行端正, 作风正 } \\
\text { 派, 公正廉洁, 无不良咺好和不良行 } \\
\text { 为记录。 }\end{array}$ & 1 \\
\hline
\end{tabular}

Tablo 4. İşilanı 2 招募二

İkinci etkinlikte reklam panolarında bulunan farklı biçimde hazırlanmış iki iş ilanı kullanılır. Öğrencilerden bu iki farklı iş ilanını okumaları istenir. İlanlardan birinde maddeler hâlinde gerekli şartlar ve özellikler sıralanmışken, diğerinde aranan şartlar beş sütunda sınıflandırılarak hazırlanmıştır. Öğrencilerin farklı formattaki iş ilanlarını tanımaları, anlamaları amaçlanır.

一、以下有李海清的个人简历, 请读后决定哪个职业对李海清更合适? 合适的画 $(\checkmark)$ 不合适的话 (x) 不提的画 (--) 。(Aşağıda Li Haiqing'in özgeçmiş bilgileri bulunmaktadır. Li Haiqing'in özgeçmişi okuduktan sonra yukarıdaki iki iş ilanından hangisinin şartlarına uyuyor/uymuyor bulunuz ve ayrıca ilanlarda bahsedilmeyen özelliği de bulunuz. İlana uygun ise $(\checkmark)$, uygun değil ise $(x)$ ilanda bulunmuyor ise (-) şeklinde tabloyu doldurunuz).

- 李海清, 女, 1994出生于土耳其伊斯坦布尔。

- 2004年就读于土耳其安卡拉大学计算机系, 学习计算机专业, 获得学士学位。

- 2009年---2013年在Erciyes大学学习经济管理, 获得经济学硕士学位。

- 2014年 ---- 2016在银行从事计算机管理工作。

RumeliDE Dil ve Edebiyat Araşttrmaları Dergisi Osmanağa Mahallesi, Mürver Çiçeği Sokak, No:14/8 Kadıköy - ISTANBUL / TÜRKIYE 34714 e-posta: editor@rumelide.com tel: +90 505 7958124, +90 2167730616
Address

RumeliDE Journal of Language and Literature Studies Osmanağa Mahallesi, Mürver Çiçeği Sokak, No:14/8

Kadıköy - ISTANBUL / TURKEY 34714

e-mail: editor@rumelide.com,

phone: +90 505 7958124, +90 216773 o 616 

李海清 Li Haiqing
招募一 İş ilanı 1
招募二 iş ilanı 2
不提 bahsedilmemiş

教育背景eğitim

工作经验 iş deneyimi

年龄 yaş

语言 yabancı dil

Tablo 5: Okuma etkinliği 2

İkinci etkinlik için iki farklı formatta iş ilanı kullanılmıştır. Bu iş ilanının altına kurgu bir özgeçmiş oluşturulmuştur. Öğrencilerden oluşturulmuş özgeçmişe göre sorulara cevap vermeleri istenmiştir. Li Haiqing eğitim, iş deneyimi, yaş, dil özellikleri açısından hangi iş ilanına başvurmaya uygun ve uygun olmadığı öğrencilerin bulması istenmiştir. Bu etkinlik ile öğrencilerin göz gezdirme, tarama, karşılaştırma ve çıkarım yapma okuduğunu anlama becerilerinin geliştirilmesi hedeflenmiştir.

Bu etkinlikten sonra üçüncü aşamada öğrencilere metinde bulunan önemli dilsel yapılar açıklanır. İş ilanlarında bulunan anlatım özellikleri ve önemli yapılar anlatılır. Yukarıda incelenen iş ilanları içinden bu yapılar bulunarak örneklendirilir.

3. Aşama Dilsel bilgi ve ödev

注解、

**从事，指投身到（某种事业中去），后面一般要带宾语。

例如：学校毕业以后, 我一直从事外贸工作。

** $\mathbf{V}+$ 于，表示在某地、某时发生什么事情，介词“于”一般在动词后面书面语用的。

例如：他毕业于安卡拉大学。

她工作于上海交通公司。

Tablo 4. Dilsel bilgi içeriği ve örnekler

Derste kullanılan fotoğraflar içinden sık kullanılan dil yapıları örneklerle öğrencilere anlatılır. Tablo 4'te özgeçmişlerde kullanılan iki farklı dilsel yapı örneklerle anlatılır.

Son aşamada ödev olarak öğrencilerden ilgilendikleri sektöre göre 3 farklı formatta hazırlanmış Çince özgün iş ilanı örnekleri bulmaları, incelemeleri ve kendi özelliklerine uyan ve uymayan özellikleri yazıp derse getirmeleri istenir. Öğrenciler ödevlerini hazırlamaları için Çin arama motoruna, baidu görsellere ve özgün sitelere yönlendirilir. Öğrencinin kendi seçtiği ve ilgi duyduğu alanla ilgili ödev hazırlaması, içsel güdülenmesini artırır. Nunan ve Lamb (1996)'a göre içsel güdülenme öğrencilerin neyi, nasıl öğrenmek istediklerini bilmeleri ve kendi öğrenme süreçlerinde sorumluluk almaları ile mümkündür. Derste ve ders dışında öğrenciye seçim fırsatı sunmak gerekmektedir.

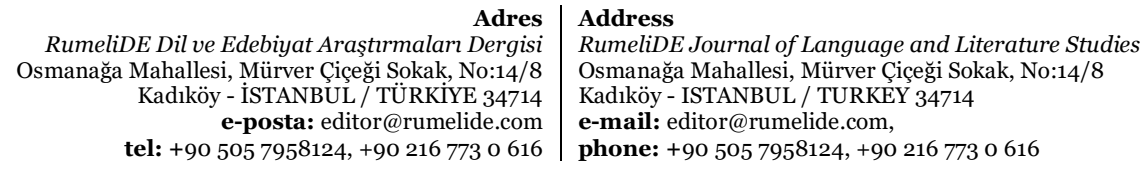




\section{Sonuç ve öneriler}

Yapay ve oluşturulmuş araçların aksine dilsel çevre araçları dilin iletişimsel işlevini öğrencilere sunması bakımından oldukça önemlidir. Dilsel çevre aracı sayesinde gerçek dil ortamında bulunan her türlü yazılı araçla karşılaşan öğrencinin dil edinim süreci daha anlamlı hale gelir. Öğrencinin gerçek dil araçlarına maruz kalması ve günlük hayatta kullanılan araçları derste görmesi, etkinlik yapması dil öğretimini etkili ve verimli hale getirebilir. Dilsel çevre bu bakımdan özellikle dil ortamında bulunmayan öğrencilerin gerçek dil kullanımı görmeleri için kullanılabilir önemli kaynaklardan sayılır. Özellikle okuma ve okuduğunu anlama becerisinin geliştirilmesine yönelik çalışmalar dilsel çevre araçları ile yapılabilir. Sayer (2010), Barrs (2016) ve Rowland (2012) dil öğretiminde dilsel çevre araçlarını kullanarak dil ediniminde olumlu sonuçlar elde etmişlerdir. Diğer dillerde yapılan çalışmalardan yola çlkılarak Çince öğretiminde de dilsel çevrenin kullanıma örnek oluşturacak bir ders izlencesi hazırlanmıştır. Hazırlanan ders izlencesinin öğrenme süreçlerine katkı sağlayacağı, öğrenmeyi daha eğlenceli, etkin ve kalııı kılacağı öngörülmüştür. Hazırlanan etkinliklerin gerçek hayata dönük olması, çeşitliliği ve görsel açıdan zengin olması öğrenci güdülenmesini artırır. Dilsel çevre araçları öğrenmenin sınıf içinden çıkıp gerçek hayata taşınması, deneyimleri unutulmaz kılar, farklı algı türlerini (görsel, işitsel, dokunsal, vb.) harekete geçirerek bunların daha kalıcı olmasını sağlayabilir. Bu ders ünitesi henüz uygulanmamış ve öğrenmeye etkisi henüz ölçülmemiş olsa da gerçek fotoğraflarla sunulan bilgilerin daha kalıcı olacağı öngörülmektedir. Sınıf içinde geleneksel ders kitaplarının ve sınıf etkinliklerinin dışında oluşturulan yenilikçi araçların kullanılması yararlı olacaktır.

Gazete, dergi, resim gibi özgün araçlar dil öğretiminde sıklıkla kullanılmaktadır. Özgün araçların kullanımı uzun yıllardır tartışma konusudur. Metinlerin zorluk düzeyi uygun seçilmediği takdirde bu metinler öğrencilere yorucu ve zorlayıcı gelip öğrencilerde başarısızlık hissi yaratabilir (Wallace, 1991). $\mathrm{Bu}$ nedenle hedef kitlenin düzeyine uygun araç seçimi oldukça önemlidir. Özgün araç olarak kabul ettiğimiz dilsel çevre araçlarında temel seviye araçları bulmak mümkündür. Özgün araçlar öğrenciye zor gelmesi nedeniyle tartışılırken yapılan uygulamalı çalışmalar özgün araçların öğrenci başarısına olumlu etkisi olduğunu göstermiştir (Nuttall, 1996).

Özgün araçlar, yabancı dil öğretimini destekleyici araç olmasının yanı sıra, daha çok bireylerin yaşamlarında iletişim aracı olarak kullanılabilir olması açısından önemlidir (Peacock, 1997). Dilsel çevre araçları, günlük yaşamın tüm yönlerini tanıtıp, özgün araçları çeşitlendirir, dolayısıyla girdinin öğrenciye aktarım yolunun çeşitlenmesi ile hedeflenen kazanımlarda başarılı olunmasını sağlayabilir.. Çin'e hiç gitmemiş, gerçek Çince iletişim ortamında bulunmamış Çince öğrenen Türk öğrencilerin günlük hayatta ve kamusal alanlarda kullanılan Çince ile karşılaşmaları, özgün araçlarla ve dilsel çevre araçları ile mümkündür. Sınıf içine taşınan dilsel çevre araçları, öğrencide gerçek dil ortamı hissi yaratır, öğrenmeyi kalıcı hâle getirebilir. Öğrencilerin metin türlerinin ve cümle kalıplarının dışına çıkarak farklı metinlerle karşılaşmalarını kolaylaştırır. Ayrıca bu metinler öğrencilerin eleştirel düşünme, iletişimsel yeterlik ve dilsel farkındalıklarını artırır. Sınıf içinde dilsel çevre ile yapılan ünitelerin, etkinliklerin ve alıştırmaların artması dil öğrenme güdülenmesini arttırır. Öğrencilerin Çin'de halkın karşılaştı̆̆ı güncel ve gerçek bir ilanı görmesi, zihninde canlandırması onların geleneksel ders araçlarına göre daha dikkat çekici olacak, onların güdülenmesini artırıp derse karşı tutumlarını değiştirebilir. Günlük hayatta sık yer alan araçların ders içinde kullanımı öğrencinin derse ilgisini canlı tutacağı için derse daha aktif katılım sağlayabilir. Bu çalışma ile öğrenciler mezun olup Çin'e gitme şansları olduğu zaman sokaklarda gördükleri reklam ve iş ilanlarını birbirinden ayırabilecekler ve gerekli durumlarda bilgilerini günlük hayatta kullanabilir olacaklardır. Ayrıca bu çalışmanın dilsel çevrenin yabancı dil olarak Çince öğretiminde kullanımına yönelik yapılan nadir çalışmalardan biri olması nedeniyle alanyazına katkı

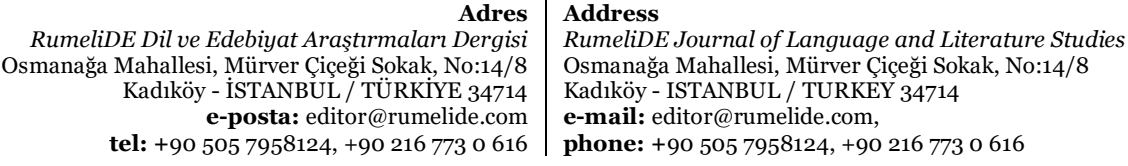


sağlayacă̆ı düşünülmektedir. Çalışma kapsamında hazırlanan ünitenin uygulama öncesi, uygulama sırası ve uygulama sonrası değerlendirilmesi ile çalışma daha değerli olacaktır. Çince öğretimi alanında yapılan çalışmalar çoğaldıkça dilsel çevre araçlarının önemi de anlaşılacaktır.

Çince yazı sisteminin kendine has yapısal özellikleri bulunmaktadır. Yazılı dilin temeli olan imler hayatın her alanında yoğun şekilde bulunmaktadır. Okuduğunu anlama becerisini geliştirmek bu yazılı dile daha fazla maruz kalmakla mümkündür. Öğrencinin daha fazla gerçek yazılı dile maruz kalması dilsel çevre araçları ile sağlanabilir. Dilsel çevre bu bakımdan öğrenci ve öğretmenlere çok sayıda çeşitli dil öğrenme araçları sunar. Dilsel çevre araçları kullanılarak farklı düzeylerde temel dil becerilerini geliştirmeye yönelik daha fazla ders aracı, ünite, izlence, ödev, proje ve etkinlik tasarlanıp, derslerde uygulanması ve değerlendirilmesi önerilir. Günümüzde öğrencilerin ve öğretmenlerin dilsel çevre araçlarına ulaşması teknolojinin gelişmesiyle oldukça kolaylaşmıştır.

\section{Kaynakça}

Cenoz, J. \& Gorter, D. (2008). The linguistic landscape as an additional source of input in second language acquisition. International Review of Applied Linguistics in Language Teaching 46(3):257-276.

Chesnut, M., Lee, V. and Schulte, J. (2013). The language lessons around us: Undergraduate English pedagogy and linguistic landscape research. English Teaching: Practice and Critique, Volume 12, Number 2: 102-120.

Corbin, J. \& Strauss, A. (2008). Basics of qualitative research: Techniques and procedures for developing grounded theory. Thousand Oaks: Sage

Barrs, K. (2016). The typology of English in Japanese society: Learning from the linguistic landscape. Proceeding of Classic 21- 29.

Gorter, D. (2006). Introduction: The study of the linguistic landscape as a new approach to multilingualism. International Journal of Multilingualism, 3(1): 1-6.

Herwitt-Bradsaw, I. (2014). Linguistic landscape as a language learning and literacy resource in Caribbean Creole contexts. Caribbean Curriculum. 22: 157-173.

Krashen, S. D. (1982). Principles and Practice in Second Language Acquisition. Pergamon Press.

Nation, I. S. P. (2009). Teaching ESL/EFL Reading and Writing. UK: Routledge .

Nunan, D. ve Lamb, C. (1996). The Self-Directed Teacher: Managing the Process. New York: Prentice Hail.

Nuttall, C. (1996). Teaching reading skills in a foreign language. Bath: Heinemann.

Peacock, M. (1997). The Effect of Authentic Materials on the Motivation of EFL Learners. ELT Journal, 51(2), 144-156.

Rowland, L. (2012). The pedagogical benefits of a linguistic landscape project in Japan. International Journal of Bilingual Education and Bilingualism 16(4):1-12.

Sayer, P. (2010). Using the linguistic landscape as a pedagogical resource. ELT Journal Volume 64(2): 143-155.

Sarosdy, J., Bencze, T., Poor, Z. \& Vadnay, M. (2006). Applied Linguistic 1 for BA Students in English. Bolcsesz Konzorcium.

Thornbury, S. (2012). L is for the linguistic landscape. https://scottthornbury.wordpress.com/2012/03/11/l-is-for-linguistic-landscape-2/

Xing, J. Z. (2006). Teaching Learning Chinese as a Foreign Language: A Pedagogical Grammar. Hongkong: Hongkong University Press.

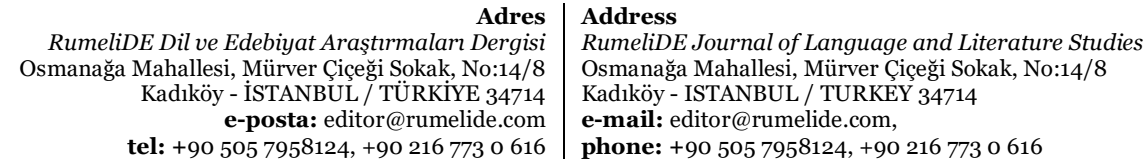
tel: +90 $5057958124,+902167730616$ 